\title{
ANALISIS PRODUKTIVITAS KERJA KARYAWAN OUTSOURCING PADA PT SIANTAR PUTRA MANDIRI
}

\author{
Agung Nugroho \\ Agungking908@ymail.com
}

\begin{abstract}
ABSTRAK
Penelitian ini bertujuan untuk menguji dan menganalisis pengaruh human capital, nformation capital, dan organisational capital terhadap produktivitas kerja. Sampel penelitian adalah karyawan outsourcing PT Siantar Putra Mandiri yang berjumlah 40 orang. Data diperoleh dari hasil penyebaan kuesioner, Analisis dilakukan dengan menggunakan regresi linear.

Berdasarkan hasil penelitian menunjukkan Human capital, berpengaruh terhadap produktivitas kerja. PT Siantar Putra Mandiri, disarankan untuk human capital (keterampilan dan keahlian) yang dimiliki oleh karyawan.
\end{abstract}

Kata kunci: human capital, produktivitas kerja

\section{PENDAHULUAN}

Salah satu faktor yang mempengaruhi tingkat keberhasilan suatu perusahaan atau organisasi adalah produktivitas kerja karyawannya. Produktivitas kerja karyawan merupakan hasil kerja secara kualitas dan kuantitas yang dicapai oleh karyawan dalam melaksanakan tugasnya sesuai dengan tanggung jawab yang diberikan kepadanya. Menurut Helmiatin (2015:52), peranan modal intelektual sangat berpengaruh terhadap produktivitas kerja karyawan dan dalam jangka panjang akan mempengaruhi kinerja organisasi, karena modal intelektual dapat digunakan organisasi untuk menciptakan kinerja yang diharapkan, dan sebagai alat evaluasi produktivitas kerja karyawan untuk menciptakan karyawan yang survive terhadap kebutuhan organisasi ke depan.

Karyawan merupakan salah satu aset utama suatu perusahaan yang menjadi perencana dan pelaku aktif dari setiap aktivitas organisasi. Mereka mempunyai pemikiran, perasaan, keinginan, status dan latar belakang pendidikan, usia dan jenis kelamin yang heterogen yang di bawa ke dalam suatu organisasi. Kualitas dan kuantitas sumber daya manusia harus sesuai dengan kebutuhan organisasi supaya efektif dan efisien menunjang tercapainya tujuan organisasi (Hasibuan, 2012:27)

Kualitas sumber daya manusia atau karyawan dapat diukur melalui produktivitas kerjanya. Produktivitas kerja karyawan menurut Gaol (2014:273) adalah perilaku nyata yang ditampilkan setiap orang sebagai prestasi kerja yang dihasilkan oleh karyawan sesuai dengan perannya di lembaga atau perusahaan. Setiap perusahaan selalu mengharapkan karyawannya mempunyai produktivitas kerja yang tinggi, karena dengan memiliki karyawan yang berproduktivitas kerja tinggi akan memberikan sumbangan yang optimal bagi perusahaan. Selain itu, dengan memiliki karyawan yang berproduktivitas kerja tinggi perusahaan dapat meningkatkan produktivitas kerjanya.

Fenomena status karyawan pada PT Siantar Putra Mandiri sering dianggap masalah krusial, yaitu antara karyawan tetap dan outsourcing, atau antara karyawan tetap dan kontrak. Kebijakan atau regulasi yang ada sering menimbulkan persoalan, khususnya di kalangan karyawan outsourcing, karena aktivitas kerja karyawan 
outsourcing dalam suatu perusahaan selalu dibayangi perasaan ketidakpastian, baik mengenai gaji, tunjangan, maupun beban pekerjaan.

Implikasi psikologis dari perasaan ketidakpastian tersebut akan tampak pada motivasi karyawan outsourcing. Namun demikian, ketidakpastian masa depan juga bisa menambah semangat kerja atau motivasi kerja karyawan outsourcing untuk semakin produktif dan mendapatkan penilaian lebih dari perusahaan, agar statusnya suatu saat dapat meningkat. Hal ini karena produktivitas kerja karyawan outsourcing, merupakan penilaian utama diangkatnya status karyawan outsourcing menjadi karyawan tetap.

PT Siantar Putra Mandiri merupakan salah satu perusahaan yang menggunakan karyawan outsourcing. Karyawan outsourcing berperan dalam membantu tugas-tugas utama yang dijalankan karyawan tetap sehingga dapat berjalan dengan baik. Secara umum, dapat dikatakan bahwa setiap perusahaan menginginkan para karyawannya untuk bekerja penuh dedikasi selama bertugas, dengan kata lain perusahaan tidak menginginkan terjadinya pemutusan kerja sehingga harus kembali merekrut karyawan baru dan akan memerlukan waktu lebih lama untuk proses perekrutan dan pelatihan.

Penelitian terhadap produktivitas kerja karyawan telah dilakukan oleh Prasetya, et al. (2016) dan Helmiatin (2015). Prasetya, et al. (2016) menemukan bahwa human capital, information capital, dan organizational capital berpengaruh signifikan terhadap produktivitas kerja karyawan, sementara hasil penelitian Helmiatin (2015) menunjukkan bahwa modal manusia tidak mempengaruhi produl ". ${ }^{\prime}$ 'ja karyawan, sedangkan modal konsumen dan modal struktural $m$ ai produktivitas kerja karyawan secara signifikan.

Berdasarkan uraian di atas, maka peneliti tertaik untuk melakukan penelıtıan dengan judul "Pengaruh Human Capital, Information Capital dan Organizational Capital terhadap Produktivitas Kerja Karyawan Outsourcing PT Siantar Putra Mandiri."

\section{TINJAUAN PUSTAKA}

\section{Human Capital}

Menurut Hidayat (2013:881), secara umum human capital selalu dikaitkan dengan keterampilan dan keahlian seseorang dalam sebuah organisasi. Menurut Divianto (2010:82), human capital di dalam organisasi memiliki potensi penuh untuk membangun orientasi pasar bagi konsumennya. Jika kompetensi pegawai di dalam suatu organisasi semakin baik, mereka akan memahami kebutuhan konsumen dan mengembangkan customer capital untuk menahan loyalitas konsumen. Di samping itu human capital juga merupakan sumber inovasi dan pembaharuan bagi perusahaan. Menurut Helmiatin (2015:53) modal manusia sebagai sumber pengetahuan yang sangat berguna, keterampilan, dan kompetensi dalam suatu organisasi atau perusahaan. Modal manusia akan meningkat jika perusahaan mampu menggunakan pengetahuan yang dimiliki karyawannya.

Human Capital adalah istilah yang dipopulerkan oleh Gary Becker, seorang ekonom dari University of Chicago, dan Jacob Mincer yang mengacu pada persediaan atribut pengetahuan, kebiasaan, sosial dan kepribadian, termasuk kreativitas, yang terkandung dalam kemampuan melakukan kerja sehingga menghasilkan nilai ekonomis (Goldin, 2014)

Sebagai alternatif, modal manusia adalah kumpulan sifat, semua pengetahuan, bakat, keterampilan, kemampuan, pengalaman, kecerdasan, pelatihan, penilaian, dan kebijaksanaan yang dimiliki secara individu dan kolektif oleh individu dalam suatu populasi. Sumber daya ini adalah kapasitas total orang-orang yang mewakili suatu 
bentuk kekayaan yang dapat diarahkan untuk mencapai tujuan negara atau negara bagian atau bagiannya. Ini adalah pandangan ekonomi secara utuh tentang manusia yang bertindak dalam ekonomi, yang merupakan upaya untuk menangkap kompleksitas sosial, biologi, budaya dan psikologis saat mereka berinteraksi dalam transaksi eksplisit dan / atau ekonomi. Banyak teori secara eksplisit menghubungkan investasi dalam pengembangan modal manusia dengan pendidikan, dan peran modal manusia dalam pembangunan ekonomi, pertumbuhan produktivitas, dan inovasi sering disebut-sebut sebagai pembenaran subsidi pemerintah untuk pendidikan dan pelatihan keterampilan kerja (Simkovic, 2013).

Istilah "Human Capital" telah dan terus dikritik dengan berbagai cara. Michael Spence menawarkan teori pensinyalan sebagai alternatif sumber daya manusia (Michael, 2002). Human Capital diasumsikan dalam teori ekonomi awal, yang mencerminkan konteksnya, yaitu sektor sekunder ekonomi menghasilkan lebih banyak daripada sektor tersier yang dapat diproduksi pada saat itu di kebanyakan negara - menjadi sumber yang mudah berubah, homogen, dan mudah dipertukarkan. Human Capital disebut hanya sebagai "tenaga kerja" atau "karyawan" saja, satu dari tiga faktor produksi (yang lain adalah tanah, dan aset aset dan peralatan fisik yang dapat dipertukarkan). Sama seperti tanah dikenali sebagai modal alam dan aset itu sendiri, faktor produksi manusia dinaikkan dari analisis mekanistik sederhana ini ke sumber daya manusia.

Konsep modal manusia relatif lebih penting di negara-negara yang kelebihan tenaga kerja. Negara-negara ini secara alami diberi lebih banyak tenaga kerja karena tingkat kelahiran lebih tinggi dibanding negara lain. Kelebihan tenaga kerja di negaranegara ini menyebabkan sumber daya manusia yang tersedia lebih banyak daripada sumber modal yang nyata. Sumber daya manusia ini dapat diubah menjadi modal manusia dengan masukan yang efektif untuk pendidikan, kesehatan dan nilai-nilai sosial. Transformasi sumber daya manusia mentah menjadi sumber daya manusia yang sangat produktif dengan masukan ini adalah proses pembentukan modal manusia (human capital). Masalah kelangkaan modal berwujud di negara-negara surplus tenaga kerja dapat diatasi dengan mempercepat laju pembentukan human capital dengan investasi swasta dan publik di bidang pendidikan dan kesehatan ekonomi nasional mereka.

Modal finansial yang nyata merupakan instrumen efektif untuk mendorong pertumbuhan ekonomi bangsa. Modal manusia tak berwujud, di sisi lain, adalah instrumen untuk mempromosikan pembangunan bangsa secara komprehensif karena sumber daya manusia berhubungan langsung dengan pembangunan manusia, dan bila ada perkembangan manusia, kemajuan kualitatif dan kuantitatif bangsa tidak dapat dielakkan lagi.

\section{Produktivitas Kerja Karyawan}

Produktivitas kerja karyawan menurut Gaol (2014:686) merupakan prestasi karyawan di lingkungan kerjanya. Dari sisi lain produktivitas kerja merupakan pemanfaatan atau penggunaan sumber daya manusia secara efektif dan efisien. Produktivitas yang tinggi merupakan cerminan pegawai yang merasa puas akan pekerjaannya dan akan memenuhi semua kewajibannya sebagai pegawai. Wartana (2011:23) mendefinisikan produktivitas kerja sebagai kemampuan seseorang untuk menghasilkan sesuatu dari tugas dan pekerjaan yang diberikan oleh perusahaan.

Produktivitas kerja menurut Sunyoto (2015: 36) secara teknis merupakan perbandingan antara hasil yang dicapai dan keseluruhan sumber daya yang 
dipergunakan. Siagian dalam Prestawan (2010) mengatakan bahwa produktivitas kerja adalah kemampuan memperoleh manfaat yang sebesar-besarnya dari sarana dan prasarana yang tersedia dengan menghasilkan output yang optimal bahkan kalau mungkin yang maksimal.

International Labour Organization (ILO) yang dikutip oleh Hasibuan (2012:127) mengungkapkan bahwa secara lebih sederhana maksud dari produktivitas adalah perbandingan secara ilmu hitung antara jumlah yang dihasilkan dan jumlah setiap sumber yang dipergunakan selama produksi berlangsung. Sedangkan pengertian produktivitas kerja menurut Ardana, dkk dalam Rumondor (2013: 1044) adalah perbandingan antara hasil yang dicapai dengan keseluruhan daya atau faktor produksi yang dipergunakan.

Menurut Nitisemito dalam Wartana (2011: 25), untuk mengukur produktivitas kerja karyawan dapat digunakan indikator sebagai berikut:

a. Kemampuan memotivasi diri

b. Membangun rasa percaya diri

c. Beranggung jawab dalam pekerjaan

d. Menyenangi pekerjaan

e. Mampu mengatasi persoalan

f. Memberi kontribusi yang positif

g. Memiliki potensi dalam pekerjaan

Menurut Simamora (2009:612) faktor-faktor yang digunakan dalam pengukuran produktivitas kerja antara lain:

a. Kuantitas kerja adalah merupakan suatu hasil yang dicapai oleh karyawan dalam jumlah tertentu dengan perbandingan standar ada atau ditetapkan oleh perusahaan.

b. Kualitas kerja adalah merupakan suatu standar hasil yang berkaitan dengan mutu dari suatu produk yang dihasilkan oleh karyawan dalam hal ini merupakan suatu kemampuan karyawan dalam menyelesaikan pekerjaan secara teknis dengan perbandingan standar yang ditetapkan oleh perusahaan.

c. Ketepatan waktu merupakan tingkat suatu aktivitas diselesaikan pada awal waktu yang ditentukan, dilihat dari sudut koordinasi dengan hasil output serta memaksimalkan waktu yang tersedia untuk aktivitas lain. Ketepatan waktu diukur dari persepsi karyawan terhadap suatu aktivitas yang disediakan diawal waktu sampai menjadi output.

\section{Faktor-Faktor yang Mempengaruhi Produktivitas Kerja Karyawan}

Payaman dalam Dewi dan Aeni (2012: 89) menyatakan bahwa produktivitas tenaga kerja dipengaruhi oleh berbagai faktor yang berhubungan dengan tenaga kerja itu sendiri maupun yang berhubungan dengan lingkungan perusahaan dan kebijaksanaan pemerintah secara keseluruhan, seperti pendidikan, ketrampilan, disiplin, sikap dan etika kerja, motivasi, gizi dan kesehatan, tingkat penghasilan, jaminan sosial, lingkungan dan iklim kerja, hubungan industrial dan kebijaksanaan pemerintah tentang produksi, investasi, perizinan, teknologi, fiskal, harga, distribusi dan lain-lain.

Faktor-faktor tersebut dapat mempengaruhi produktivitas kerja karyawan baik secara langsung tidak langsung. Produktivitas kerja juga dipengaruhi tingkat kehadiran karyawan dalam tempat kerja atau absen karyawan. Produktivitas tidak mungkin tercapai secara optimal jika tingkat kehadiran karyawan sangat rendah. 
Sedangkan menurut Sedarmayanti dalam Wartana (2011: 24) faktor-faktor yang mempengaruhi produktivitas kerja karyawan adalah sebagai berikut:

a. Tindakan konstruktif

b. Percaya pada diri sendiri

c. Bertanggung jawab

d. Memiliki rasa cinta terhadap pekerjaan

e. Mempunyai pandangan ke depan

f. Mampu mengatasi persoalan dan dapat menyesuaikan diri dengan lingkungan yang berubah-ubah.

g. Mempunyai kontribusi positif terhadap lingkungan.

h. Memiliki kekuatan untuk mewujudkan potensi yang dimiliki.

i. Semangat kerja untuk mendorong mereka untuk bekerjasama dalam menyelesaikan pekerjaan.

\section{Hipotesis Penelitian}

Hipotesis dibangun atas permasalahan yang ada dan landasan teori yang dikemukakan, maka disusun hipotesis penelitian sebagai berikut:

1. Human capital berpengaruh signifikan terhadap produktivitas kerja karyawan outsourcing PT Siantar Putra Mandiri.

\section{METODE PENELITIAN \\ Jenis Penelitian}

Jenis penelitian yang digunakan bila dilihat dari pengukuran variabel adalah kuantitatif karena datanya bisa diukur dengan angka menggunakan skala likert untuk mengkuantitatifkan variabel yang pada mulanya adalah kualitatif. Bila dilihat dari populasi yang digunakan, penelitian ini termasuk penelitian sensus, karena semua populasi digunakan sebagai objek penelitian. Bila dilihat dari hubungan antar variabel, maka penelitian ini termasuk penelitian korelasional, yaitu penelitian yang bertujuan untuk mengukur hubungan antar variabel.

Rancangan dalam penelitian ini merupakan penelitian field research yang dikelompokkan ke dalam jenis penelitian survey karena peneliti menggunakan survey dalam memperoleh data dan keterangan langsung pada obyek penelitian dengan cara penyebaran kuesioner.

\section{Populasi Penelitian}

Populasi dalam penelitian ini adalah semua Karyawan Outsourcing PT Siantar Putra Mandiri yang berjumlah 543 orang. Sampel diambil dalam penelitian ini didasarkan atas pendapat Roscoe dalam Sugiyono (2011:90) yang menyatakan bahwa bila dalam penelitian akan dilakukan analisis dengan multivariate (korelasi atau regresi ganda misalnya), maka jumlah anggota sampel minimal 10 kali dari jumlah variabel yang diteliti.

\section{Teknik Analisis Data}

\section{Analisis Regresi Linier Berganda}

Analisis regresi linier berganda digunakan untuk mengukur ada atau tidaknya hubungan antara dua variabel atau lebih dan juga menunjukkan arah hubungan antara variabel independen terhadap variabel dependen (Ghozali, 2013:96). Dalam penelitian ini analisis regresi linier berganda digunakan untuk mengukur ada atau tidaknya 
pengaruh antara human capital, sebagai variabel independen terhadap produktivitas kerja karyawan sebagai variabel dependen.

\section{Koefisien Determinasi Berganda $\left(\mathbf{R}^{2}\right)$}

Analisis koefisien determinasi berganda $\left(R^{2}\right)$ menurut Ghozali (2013:97) digunakan untuk mengukur seberapa jauh kemampuan model dalam menerangkan variasi variabel dependen. Nilai $R^{2}$ adalah antara 0 sampai 1 . Nilai $R^{2}$ yang kecil menunjukkan kemampuan variabel-variabel independen dalam menjelaskan variasi variabel dependen sangat terbatas. Nilai yang mendekati satu berarti variabel-variabel independen memberikan hampir semua informasi yang dibutuhkan untuk memprediksi variasi variabel dependen.

Dalam penelitian ini analisis koefisien determinasi berganda digunakan untuk mengukur seberapa besar variasi naik turunnya variabel human capital $\left(\mathrm{X}_{1}\right)$, information capital $\left(\mathrm{X}_{2}\right)$, dan organisational capital $\left(\mathrm{X}_{3}\right)$ dapat mempengaruhi variasi naik turunnya produktivitas kerja karyawan $(\mathrm{Y})$.

\section{Uji Pengaruh Simultan dengan Uji F}

Uji F pada dasarnya digunakan untuk menunjukkan pengaruh secara simultan variabel independen terhadap variabel dependen. Kriteria pengujian uji $F$ menurut Ghozali (2013:98) adalah jika nilai probabilitas lebih kecil dari 0,05 maka secara simultan variabel independen berpengaruh terhadap variabel dependen.

\section{Uji Pengaruh Parsial dengan Uji t}

Uji $\mathrm{t}$ pada dasarnya menunjukkan seberapa besar pengaruh satu variabel independen secara individual dalam menerangkan variasi variabel dependen. Kriteria pengujian uji t menurut Ghozali (2013:98) adalah jika nilai probabilitas lebih kecil dari 0,05 maka secara parsial variabel independen berpengaruh terhadap variabel dependen.

\section{HASIL PENELITIAN DAN PEMBAHASAN}

\section{Uji Asumsi Klasik}

\section{Uji Normalitas Data}

Uji normalitas bertujuan untuk menguji apakah dalam model regresi variabel pengganggu atau residual memiliki distribusi normal atau tidak. Salah satu cara untuk melihat normalitas residual adalah dengan melihat grafik histrogram. Dasar pengambilan keputusan menurut Ghozali (2013:161) adalah:

a. Jika data menyebar di sekitar garis diagonal dan mengikut arah garis diagonal, maka model regresi memenuhi asumsi Normalitas.

b. Jika data menyebar jauh dari garis diagonal dan/atau tidak mengikuti arah garis diagonal, maka model regresi tidak memenuhi asumsi Normalitas.

Dari hasil pengolahan data dengan program SPSS 20 diperoleh hasil sebagai berikut: 


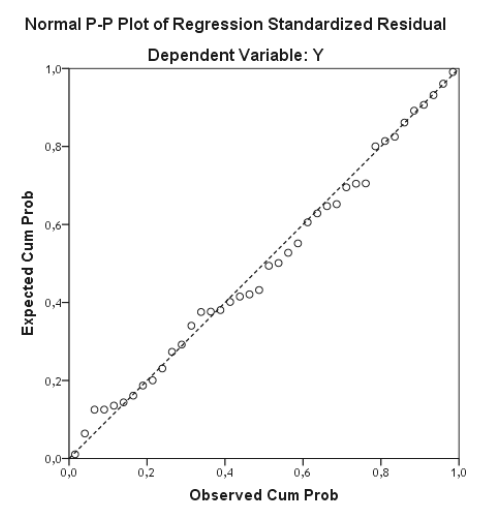

Gambar 1

Uji Normalitas

Dari gambar normal probability plot di atas diketahui data menyebar di sekitar garis diagonal dan mengikut arah garis diagonal, hal ini menunjukkan bahwa data terdistribusi secara normal.

\section{Uji Multikolinearitas}

Uji multikolinearitas bertujuan untuk menguji apakah model regresi ditemukan adanya korelasi antar variabel bebas. Menurut Ghozali (2013:106), nilai cut off yang digunakan untuk menunjukkan adanya multikolinearitas adalah:

a. Jika nilai tolerance $<0,10$ dan VIF $>10$, maka terdapat korelasi yang terlalu besar di antara salah satu variabel bebas dengan variabel-variabel bebas yang lain (terjadi multikolinearitas).

b. Jika nilai tolerance $>0,10$ dan VIF $<10$, maka tidak terjadi multikolinearitas.

Dari hasil pengolahan data dengan program SPSS 20 diperoleh hasil sebagai berikut:

Tabel 1

Nilai Tolerance Dan VIF

\begin{tabular}{llrr}
\hline \hline Model & \multicolumn{2}{c}{ Collinearity Statistics } \\
\cline { 3 - 4 } & & Tolerance & \multicolumn{2}{c}{ VIF } \\
\hline \multirow{3}{*}{1} & X1 & & \\
& X2 &, 509 & 1,966 \\
& X2 &, 559 & 1,788 \\
& X3 &, 533 & 1,875 \\
\hline \hline
\end{tabular}

Dari tabel di atas diketahui bahwa ketiga variabel bebas human capital $\left(\mathrm{X}_{1}\right)$, information capital $\left(\mathrm{X}_{2}\right)$, dan organisational capital $\left(\mathrm{X}_{3}\right)$ memiliki nilai tolerance lebih besar dari 0,1 dan VIF lebih kecil dari 10, maka penelitian ini bebas dari multikolinearitas.

\section{Uji Heteroskesdastisitas}

Uji Heteroskedastisitas bertujuan untuk mengetahui apakah dalam sebuah model regresi terjadi ketidaksamaan varian residual dari pengamatan satu ke pengamatan yang lain. Menurut Ghozali (2013:139) deteksi ada atau tidaknya heteroskedastisitas dapat dilakukan dengan melihat ada atau tidaknya pola tertentu pada grafik scatter plot dengan dasar analisis sebagai berikut: 
a. Jika ada pola tertentu, seperti titik-titik yang ada membentuk pola tertentu yang teratur (bergelombang, melebar, kemudian menyempit), maka mengindikasikan telah terjadi heteroskedastisitas.

b. Jika tidak ada pola yang jelas serta titik-titik menyebar di atas dan di bawah angka 0 pada sumbu Y, maka tidak terjadi heteroskedastisitas.

Dari hasil pengolahan data dengan program SPSS diperoleh hasil sebagai berikut:

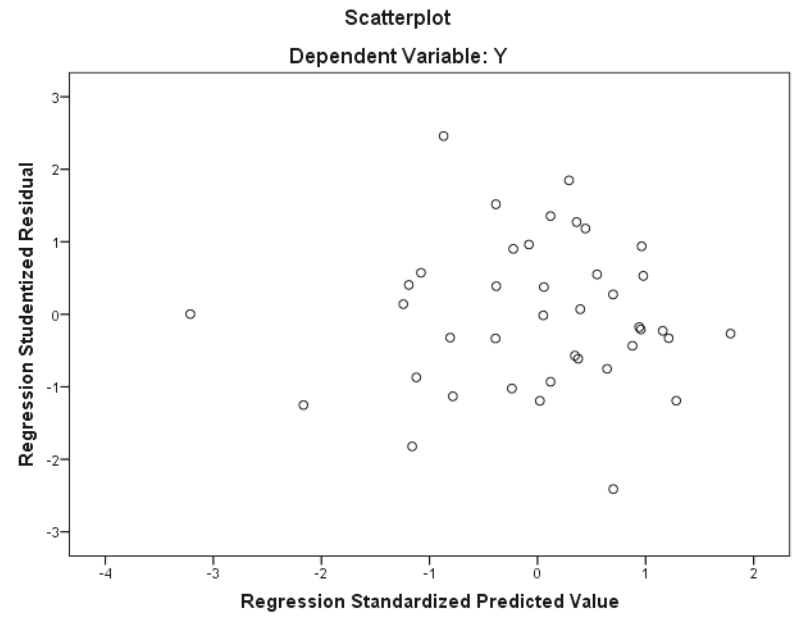

Gambar 2

Uji Heteroskedastisitas

Dari gambar di atas diketahui bahwa tidak ada pola yang jelas serta titik-titik menyebar di atas dan di bawah angka 0 pada sumbu $Y$, maka data yang digunakan tidak terjadi heteroskedastisitas.

Analisis Regresi Linier Berganda

Analisis regresi linier berganda pada penelitian ini digunakan untuk mengukur besarnya pengaruh antara human capital $\left(\mathrm{X}_{1}\right)$, information capital $\left(\mathrm{X}_{2}\right)$, dan organisational capital $\left(\mathrm{X}_{3}\right)$ terhadap produktivitas kerja karyawan $(\mathrm{Y})$. Persamaan regresi linier berganda yang didapat dari pengolahan data dengan menggunakan program SPSS 20 adalah:

Tabel 2

Regresi Linier

Coefficientsa

\begin{tabular}{|c|c|c|c|c|c|c|c|}
\hline \multirow[t]{2}{*}{ Model } & \multicolumn{2}{|c|}{$\begin{array}{c}\text { Unstandardized } \\
\text { Coefficients }\end{array}$} & \multirow{2}{*}{$\begin{array}{c}\text { Standardized } \\
\text { Coefficients } \\
\text { Beta }\end{array}$} & \multirow[t]{2}{*}{$\mathrm{t}$} & \multirow[t]{2}{*}{ Sig. } & \multicolumn{2}{|c|}{$\begin{array}{l}\text { Collinearity } \\
\text { Statistics }\end{array}$} \\
\hline & B & $\begin{array}{l}\text { Std. } \\
\text { Error }\end{array}$ & & & & $\begin{array}{c}\text { Toleranc } \\
\text { e }\end{array}$ & VIF \\
\hline (Constant) & 143 & ,338 & & 423 & 675 & & \\
\hline $\mathrm{X} 1$ & ,532 & 107 & ,544 & 4,981 & ,000 & ,509 & 1,966 \\
\hline
\end{tabular}

a. Dependent Variable: $Y$

Persamaan regresi linier berganda yang didapat dari tabel di atas adalah: $\mathrm{Y}=0,143+0,532 \mathrm{X}_{1}$

Dari persamaan persamaan regresi linier berganda tersebut dapat diintepretasikan sebagai berikut: 
1. Nilai kostanta sebesar 0,143 . Hal ini berarti bahwa jika koefisien human capital $\left(\mathrm{X}_{1}\right)$, information capital $\left(\mathrm{X}_{2}\right)$, dan organisational capital $\left(\mathrm{X}_{3}\right)$ bernilai nol, maka nilai produktivitas kerja $(\mathrm{Y})$ sebesar 0,143 satuan.

2. Nilai koefisien human capital $\left(X_{1}\right)$ bernilai positif yaitu sebesar 0,532 . Artinya human capital $\left(\mathrm{X}_{1}\right)$ berpengaruh positif terhadap produktivitas kerja $(\mathrm{Y})$. Jika human capital $\left(\mathrm{X}_{1}\right)$ mengalami peningkatan sebesar satu satuan, maka produktivitas kerja $(\mathrm{Y})$ juga akan meningkat sebesar 0,532 satuan dan sebaliknya jika human capital $\left(\mathrm{X}_{1}\right)$ mengalami penurunan sebesar satu satuan, maka produktivitas kerja (Y) juga akan turun sebesar 0,532 satuan dengan asumsi variabel information capital $\left(\mathrm{X}_{2}\right)$ dan organisational capital $\left(\mathrm{X}_{3}\right)$ besarnya tetap.

\section{Analisis Koefisien Determinasi ( $\left.\mathbf{R}^{2}\right)$}

Analisis koefisien determinasi $\left(\mathrm{R}^{2}\right)$ digunakan untuk mengukur seberapa besar variabel human capital $\left(\mathrm{X}_{1}\right)$, information capital $\left(\mathrm{X}_{2}\right)$, dan organisational capital $\left(\mathrm{X}_{3}\right)$ dapat menjelaskan atau mempengaruhi variabel produktivitas kerja $(\mathrm{Y})$. Nilai $\mathrm{R}^{2}$ adalah antara 0 sampai 1 . Nilai $\mathrm{R}^{2}$ yang kecil menunjukkan kemampuan variabel-variabel independen dalam menjelaskan variasi variabel dependen sangat terbatas. Nilai yang mendekati satu berarti variabel-variabel independen memberikan hampir semua informasi yang dibutuhkan untuk memprediksi variasi variabel dependen. Nilai koefisien determinasi $\left(R^{2}\right)$ yang didapat dari hasil pengolahan data dengan menggunakan program SPSS 20 adalah:

\section{Tabel 3}

Koefisien Determinasi Berganda Model Summary ${ }^{\mathrm{b}}$

\begin{tabular}{llrrrr}
\hline \hline Model & $\mathrm{R}$ & R Square & $\begin{array}{c}\text { Adjusted R } \\
\text { Square }\end{array}$ & $\begin{array}{c}\text { Std. Error of the } \\
\text { Estimate }\end{array}$ & $\begin{array}{c}\text { Durbin- } \\
\text { Watson }\end{array}$ \\
\hline 1 &, $884^{\mathrm{a}}$ &, 782 &, 764 &, 22629 & 2,203 \\
\hline \hline
\end{tabular}

a. Predictors: (Constant), X3, X2, X1

b. Dependent Variable: $Y$

Dari tabel di atas dapat diketahui bahwa nilai koefisien determinasi berganda ( $R$ Square) adalah sebesar 0,782 atau $78,2 \%$. Hal ini menunjukkan bahwa persentase pengaruh antara human capital $\left(\mathrm{X}_{1}\right)$, information capital $\left(\mathrm{X}_{2}\right)$, dan organisational capital $\left(\mathrm{X}_{3}\right)$ terhadap produktivitas kerja $(\mathrm{Y})$ sebesar $78,2 \%$ sedangkan sisanya sebanyak $21,8 \%$ dipengaruhi oleh variabel lain diluar penelitian.

\section{Uji F}

Uji $\mathrm{F}$ digunakan untuk mengetahui pengaruh simultan antara variabel human capital $\left(\mathrm{X}_{1}\right)$, information capital $\left(\mathrm{X}_{2}\right)$, dan organisational capital $\left(\mathrm{X}_{3}\right)$ terhadap produktivitas kerja (Y). Kriteria uji F dalam penelitian ini adalah sebagai berikut:

1. Jika nilai probabilitas atau nilai signifikasi $>0,05$ maka secara simultan human capital $\left(\mathrm{X}_{1}\right)$, information capital $\left(\mathrm{X}_{2}\right)$, dan organisational capital $\left(\mathrm{X}_{3}\right)$ tidak berpengaruh terhadap produktivitas kerja $(\mathrm{Y})$

2. Jika nilai probabilitas atau nilai signifikasi $\leq 0,05$ maka secara simultan human capital $\left(\mathrm{X}_{1}\right)$, information capital $\left(\mathrm{X}_{2}\right)$, dan organisational capital $\left(\mathrm{X}_{3}\right)$ berpengaruh terhadap produktivitas kerja $(\mathrm{Y})$

Dari hasil pengolahan data dengan menggunakan program SPSS 20 didapatkan hasil sebagai berikut:

\section{Tabel 4}

\section{Uji Pengaruh Simultan}


ANOVAa $^{a}$

\begin{tabular}{rlrrrrr}
\hline \hline Model & & $\begin{array}{c}\text { Sum of } \\
\text { Squares }\end{array}$ & df & Mean Square & F & Sig. \\
\hline \multirow{2}{*}{1} & Regression & 6,604 & 3 & 2,201 & 42,993 &, $000^{\mathrm{b}}$ \\
& Residual & 1,843 & 36 &, 051 & & \\
& Total & 8,448 & 39 & & & \\
\hline \hline
\end{tabular}

a. Dependent Variable: $Y$

b. Predictors: (Constant), X3, X2, X1

Dari tabel di atas dapat diketahui bahwa nilai signifikansi lebih kecil dari 0,05 yaitu 0,000 . Hal ini menunjukkan bahwa secara simultan human capital $\left(\mathrm{X}_{1}\right)$, information capital $\left(\mathrm{X}_{2}\right)$, dan organisational capital $\left(\mathrm{X}_{3}\right)$ berpengaruh terhadap produktivitas kerja $(\mathrm{Y})$.

Human capital $\left(\mathrm{X}_{1}\right)$ berpengaruh terhadap produktivitas kerja $(\mathrm{Y})$ karena mempunyai nilai signifikasi lebih kecil dari 0,05 yaitu 0,000. Hasil penelitian ini menunjukkan bahwa kemampuan dan keterampilan yang dimiliki karyawan dapat mempengaruhi produktivitas kerja karyawan outsourcing PT Siantar Putra Mandiri. Human capital mencerminkan kemampuan kolektif perusahaan untuk menghasilkan solusi terbaik berdasarkan pengetahuan yang dimiliki oleh orang-orang yang ada dalam perusahaan tersebut. Hasil penelitian ini mendukung penelitian yang dilakukan oleh Faturachman (2013) dengan hasil penelitian human capital berpengaruh terhadap kinerja karyawan.

\section{PENUTUP}

\section{Simpulan}

Berdasarkan hasil penelitian, maka kesimpulan yang didapat dari penelitian ini adalah sebagai berikut:

1. Human capital $\left(\mathrm{X}_{1}\right)$, information capital $\left(\mathrm{X}_{2}\right)$, dan organisational capital $\left(\mathrm{X}_{3}\right)$ secara simultan berpengaruh terhadap produktivitas kerja (Y). Hal ini dibuktikan dengan uji $\mathrm{F}$ yang menunjukkan nilai signifikasi lebih kecil dari 0,05 yaitu 0,000..

2. Human capital $\left(X_{1}\right)$, information capital $\left(X_{2}\right)$, dan organisational capital $\left(X_{3}\right)$ secara parsial berpengaruh terhadap produktivitas kerja $(\mathrm{Y})$. Hal ini dibuktikan dengan uji t yang menunjukkan nilai signifikasi semua variabel bebas lebih kecil dari 0,05.

3. Human capital $\left(\mathrm{X}_{1}\right)$ berpengaruh dominan terhadap produktivitas kerja karyawan. Hal ini dibuktikan dengan uji t yang menunjukkan nilai signifikasi variabel human capital $\left(\mathrm{X}_{1}\right)$ lebih kecil dari nilai signifikasi variabel information capital $\left(\mathrm{X}_{2}\right)$ dan organisational capital $\left(\mathrm{X}_{3}\right)$ yaitu sebesar 0,000 ..

\section{Saran}

Berdasarkan hasil penelitian dan simpulan yang telah diambil maka saran-saran yang dapat diajukan yang berkaitan dengan penelitian ini sebagai berikut:

1. Bagi PT Siantar Putra Mandiri, disarankan untuk human capital (keterampilan dan keahlian) yang dimiliki oleh karyawan, information capital yang ada di perusahaan, dan juga organizational capital yang ada di perusahaan karena dari hasil penelitian human capital, information capital, dan organisational capital baik secara simultan mapun parsial berpengaruh terhadap produktivitas kerja karyawannya.

2. PT Siantar Putra Mandiri sebaiknya lebih mengutamakan dan memperhatikan human capital (keterampilan dan keahlian) yang dimiliki oleh karyawan karena 
dari hasil penelitian human capital berpengaruh dominan terhadap produktivitas kerja karyawannya.

3. Untuk mendukung hasil penelitian ini disarankan kepada peneliti-peneliti selanjutnya untuk melakukan penelitian serupa dengan menambahkan objek penelitian yang lain serta menambahkan variabel-variabel lain yang dapat mempengaruhi kepuasan kerja karyawan agar hasil penelitian dapat lebih lengkap.

\section{DAFTAR PUSTAKA}

Alimudin, A., \& Artaya, I. P. (2009). Persepsi Nasabah Tentang Ketanggapan, Keramahan, Kehandalan, Komunikasi, Dan Mengerti Nasabah Terhadap Pelayanan Bagian Prioritas PT. Bank Central Asia Surabaya. Bisnis Dan Manajemen, 1(2).

Alimudin, A. (2017). Model of Customer Value Approach for Improving Satisfaction of the Hospital Patients. SINERGI: Jurnal Ilmiah Ilmu Manajemen, 7(2).

Alimudin, A., Septian, D., Sasono, A. D., \& Wulandari, A. (2017). Effect of Spiritual Leadership to Organizational Culture and Employee's Loyalty. Jurnal Terapan Manajemen Dan Bisnis, 3(2), 76-86.

Darmadi, Hamid. 2011. Metode Penelitian Penelitian. Penerbit Alfabeta. Bandung.

Dewi, Iis Puspika dan Nur Aeni. 2012. Pengaruh Disiplin Kerja Terhadap Produktivitas Pegawai Pada Rutan Kelas 1 Di Bandar Lampung. Jurnal Organisasi dan Manajemen. Volume 2. No. 2. Hal: 85-95.

Gaol, Jummy L. Human Capital Manajemen Sumber Daya Manusia. 2014. Penerbit PT. Gramedia Widiasarana Indonesia. Jakarta.

Ghozali, Imam. 2005. Aplikasi Analisis Multivariate Dengan Program SPSS. Badan Penerbit Universitas Diponegoro. Semarang.

Handaru, A. W, Try Utomo, dan I Ketut R Sudiarditha. 2013. Pengaruh Lingkungan Kerja, Kompensasi Dan Komitmen Organisasi Terhadap Kepuasan Kerja Karyawan Di RS "X". Jurnal Riset Manajemen Sains Indonesia. Volume 4. No. 1. Hal: 116-135.

Handoko, T. Hani. 2011. Manajemen Personalia dan Sumberdaya Manusia. Edisi Kedua. Cetakan Kedelapan belas. Penerbit BPFE. Yogyakarta.

Hasibuan, Malayu S.P. 2012. Manajemen Sumber Daya Manusia. Edisi Revisi. Penerbit Bumi Aksara. Jakarta.

Nawawi, Hadari. 2008. Evaluasi dan Manajemen Kinerja Di Lingkungan Perusahaan dan Industri. Penerbit Gadjah Mada University Press. Yogyakarta.

Nitisemito, S. Alex. 2006. Manajemen Personalia. Penerbit Ghalia Indonesia. Jakarta.

Rumondor, Vico Wentri. 2013. Motivasi, Disiplin Kerja, Dan Kepemimpinan Terhadap Produktivitas Kerja Pada Badan Kepegawaian Dan Diklat Daerah Minahasa Selatan. Jurnal Emba. Volume 1 No. 4. Hal: 1042-1052.

Siagian, Sondang P. 2009. Manajemen Sumber Daya Manusia. Edisi Satu. Cetakan Ketujuh belas. Penerbit Bumi Aksara. Jakarta.

Sugiyono. 2011. Metode Penelitian Kuantitatif Kualitatif dan RED. Cetakan Ke-13. Penerbit Alfabeta. Bandung.

Sunyoto, Danang. 2015. Penelitian Sumber Daya Manusia. Penerbit PT. Buku Seru. Jakarta. 
Wartana, I Made Hedy. 2011. Faktor - Faktor Yang Mempengaruhi Produktivitas Kerja Karyawan Pada Como Shambala Estate At Begawan Giri Ubud Bali. Jurnal Perhotelan dan Pariwisata. Volume 1 No.1. Hal: 14-34. 